\title{
Determination of stress orientation in Sabzevar Ophiolite Zone in (Khorasan Razavi Province, Iran)
}

\author{
Seyed Hossein Mirzeinaly Yazdi ${ }^{*}$, Mohsen Pourkermani ${ }^{2}$, Mehran Arian ${ }^{1}$ and Azam Karkheiran ${ }^{1}$ \\ ${ }^{1}$ Department of Geology, Science and Research Branch, Islamic Azad University, Hesarak, Tehran-Iran \\ ${ }^{2}$ Department of Geology, North Tehran Branch Islamic Azad University, Tehran, Iran \\ "mirzeinaly@gmail.com; mohsenjami84@yahoo.com
}

\begin{abstract}
Sabzevar ophiolite zone (SOZ) is in north of Central Iran that separated Kop-e-Dagh Sedimentary basin (in north) from the Central Iran plateau (in South). The evolution and replace time of this ophiolite complex has been respectively in upper Cretaceous and Middle Campanian to Upper Mastrishtian. This ophiolite belt contains a large amount of ultramafic rocks, small masses of Gabbro and thick sequence of submarine basaltic lavas. This study surveys the brittle structures that developed during the mountain building process to decipher the history of polyphase deformation. Analytic inversion techniques enabled us to determine and separate different brittle tectonic regimes in terms of stress tensors. Results indicate that oldest generation of stress on the area after the adoption of the ophiolite (Middle Campanian to Late Mastrishtian), is the tensile stress regime. Average direction of $\sigma_{1}$ stress axis in this regime is $251 / 81$. This tension is Because of subsidence of ophiolites after the adoption (located) on ground surface. Middle generation of stress has been strike slip regime and average direction of $\sigma_{2}$ stress axis in this regime is $323 / 62$. Finally, the newest generation of stress is compressional regime with an average direction of $\sigma_{3}$ stress axis 308/81. In this regime $\sigma_{1}$ direction is $183 / 05$ that has caused re activity of main pre-existing structures with N121 direction. Our reconstruction of stress fields suggests an anticlockwise reorientation of the horizontal $\sigma_{1}$ axis since the located of ophiolites on the ground and a significant change in vertical stress from $\sigma_{1}$ to $\sigma_{3}$ since the late stage of thrusting. Transition from tension to compression has been strike slip movement. Ratio of elliptical stress in any of the regimes, respectively, from old to new is $0.63,0.75$ and 0.62 that due to overcome of shear regimes, average form of stress elliptical in area, is intermediate between the prolate and oblate forms.
\end{abstract}

Keywords: Compressive tectonic, Analytic inversion, Stress tensor, Ophiolite complex

\section{Introduction}

The study area is located in the northwestern Sabzevar city (Iran) between $57^{\circ} 2^{\prime}$ to $57^{\circ} 27^{\prime}$ longitude and $36^{\circ} 22^{\prime}$ to $36^{\circ} 30^{\prime}$ latitude. Fig. 1 shows geographical location of study area. Due to expansion and diversity of rock units in the region, each of the units based on litology, geological structures and erosion type, have created a special geological forms. In terms of topography, mountainous area has been shaped by Cretaceous peridotites and submarine lava flows, Eocene lava and hyaloclastics, upper Cretaceous-Paleocene limestones and Pliocene conglomerate.

Miocene sedimentary rocks are exposed in areas of lower elevations. At present, south of Sabzevar basin is coverd by Quaternary sediments. The center complex is composed of peridotite masses that are surrounded by external zone. In the marginal zone, there are tectonic melanges. That is composed with highly deformed serpentines, Gabbro masses, basaltic and pillow lavas, and cutting by various dyke groups. Functions of tectonic structures in this complex indicated the activity of reverse and strike slip faults, especially in the marginal zone. Mantle deformation affects the mineral texture of peridotites, In addition to the present active tectonics (Stocklin, 1968).

In this paper, we aim to decipher polyphase deformation and paleo-stress history in the Sabzevar ophiolite zone on brittle tectonic studies and systematic stress inversion of fault slip data obtained from the SOZ. According to structural map and reverse faults, it is found that $\mathrm{SOZ}$ is a convergent zone. However, this paper focuses on the history of convergence in the $\mathrm{SOZ}$ in terms of stress reorientation. To achieve this purpose, the direct inversion method is used, after the structural mapping (Fig.2) and faults movement evidence recording.

\section{Geology and tectonics}

According to studies, three main ophiolite belts in Iran can be identified that include: Paleozoic ophiolite belt that is in the northern part of Iran; Parallel belt to the Zagros-Baluchestan-Oman; Ophiolite belt around the central Iran

Study area is part of Sabzevar ophiolite belt in north of Central Iran (north of Great Kavir fault) that separated Kop e Dagh 
sedimentary basin (in north) of the Central Iran plateau (in South) (Nabavi, 1976). Ophiolit belt north of Sabzevar is the horst with E-W trend that separated south regions (Sabzevar plain) from north regions (Jovein plain). This ophiolite belt that forms the highest parts of Joghatay mountains, contains a large amount of ultramafic rocks (Harzburgite and a little Dunite and Lerzolite) small masses of gabbro and thick sequence of submarine basaltic lavas with upper Cretaceous pelagic limestone and Radiolarite that as angular unconformity and with a base of conglomerates is covered by the volcanic and sedimentary-volcanic rocks. The evolution time of this ophiolite complex has been in upper Cretaceous (Santonian-Campanian) and replacement and mixing time of them is before the middle Eocene (Mirzeinali, 2012).

Fig.1. Geographical location of study area

Fig.2. Structural maps of sabzevar ophiolite zone, (a) eastern part, (b) western part.
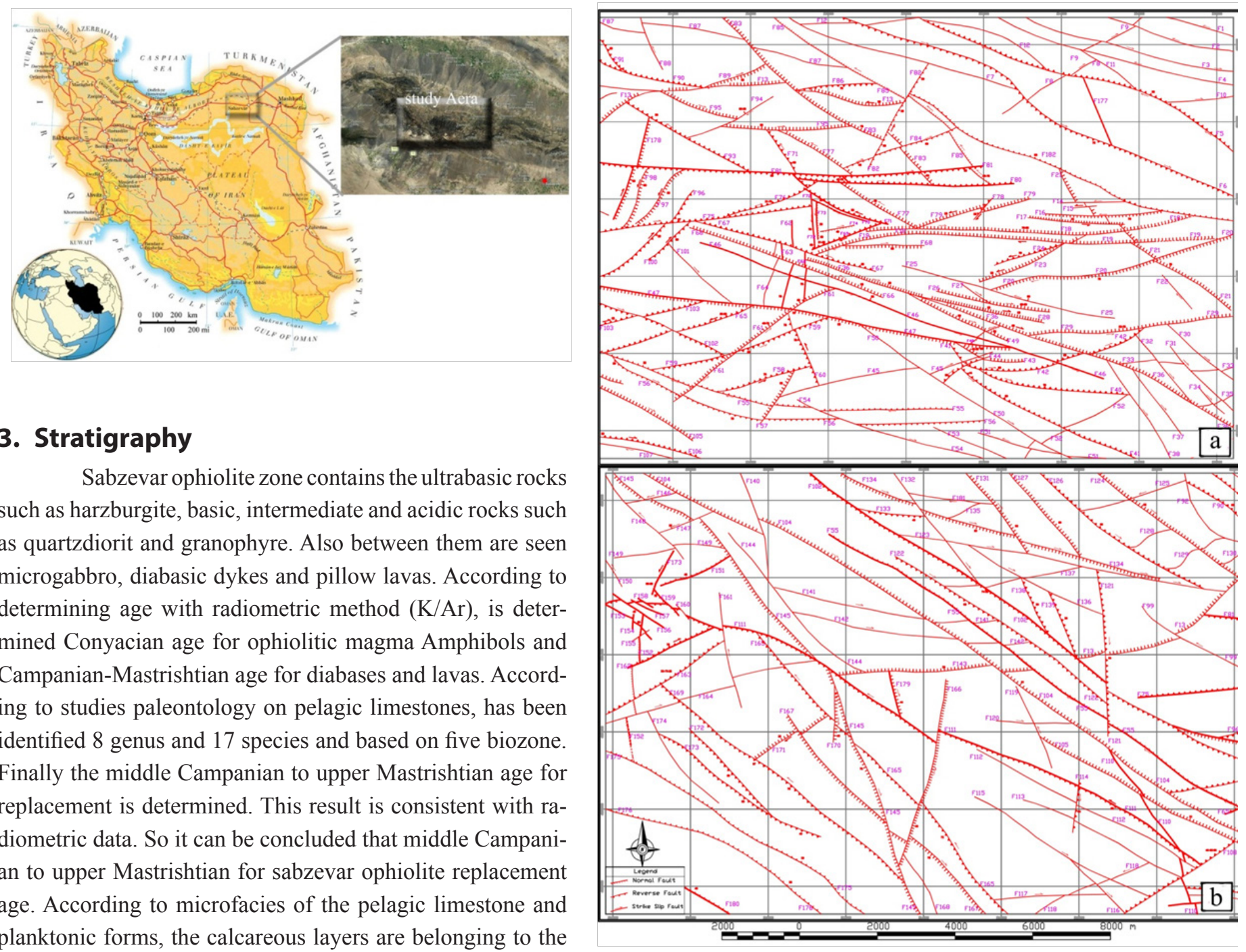

\section{Stratigraphy}

Sabzevar ophiolite zone contains the ultrabasic rocks such as harzburgite, basic, intermediate and acidic rocks such as quartzdiorit and granophyre. Also between them are seen microgabbro, diabasic dykes and pillow lavas. According to determining age with radiometric method (K/Ar), is determined Conyacian age for ophiolitic magma Amphibols and Campanian-Mastrishtian age for diabases and lavas. According to studies paleontology on pelagic limestones, has been identified 8 genus and 17 species and based on five biozone. Finally the middle Campanian to upper Mastrishtian age for replacement is determined. This result is consistent with radiometric data. So it can be concluded that middle Campanian to upper Mastrishtian for sabzevar ophiolite replacement age. According to microfacies of the pelagic limestone and planktonic forms, the calcareous layers are belonging to the deep-water fauna and have been deposited in below of CCD (Vahidinia, 1999). Generally in study area there is five main groups of litology that relationship between different units are faulting mostly and from old to new are (Bahroudi, 1999): Ultramafic-ophiolit rocks; Cretaceous volcanic-sedimentary row; Eocen volcanic-sedimentary row; Neogeneclastic deposits; Quaternary deposits.

\section{Brittle tectonics methodology}

The tectonic events that have affected the SOZ have produced a wide range of regional scale (folds, thrusts and strike-slip faults) and mesoscale (faults, joints, tension gashes) structures that indicate an evolving stress field with time. We used systematic brittle tectonic analyses, including stress tensor inversion, to decipher the succession of deformational events that resulted in the present-day structure. The common steps in these analyses involve data collection in the field, data separation and age recognition, computation of stress fields, and finally characterisation and classification of different events. 


\subsection{Fault slip measurements}

A majority of the brittle structures that we collected has associated fault slip data (strike-slip, reverse, normal, and obliqueslip). These data include the orientation of fault surfaces, slickenside lineation, and sense of motion indicators where available. Many faults $(\sim 10 \%)$ belong to simple conjugate type patterns.

Such associations facilitated quick preliminary interpretation in the field. However, some of fault slip data ( 20\%) could not unambiguously be interpreted as simple geometrical terms in the studied outcrops, because they are a result of reactivation on earlier fractures and do not conform to simple, conjugate-like models. A widespread difficulty in interpreting the measurements within the frame of polyphase brittle tectonism was related to the heterogeneity of data sets in the studied area. Because of the large heterogeneity, computing an average stress regime was meaningless.

We separated the data sets into more mechanically homogeneous subsets that this subject may correspond to distinct tectonic events. Various criteria are used to establish a relative age relationship among structures, including crosscutting relationships (Fig.3a) and successive striae observed on fault surfaces (Fig.3b), indicating fault reactivation under a new stress field (Navabpour et al., 2007). Recorded separated about 163 sliken side and in study area. However determined tree data set: newest, middle and oldest generation. Fig.4 shows faults plans, slikensides position and types of movement them.

Fig.3. Brief key to the brittle tectonic measurements and stress determinations. (a) Cross-cutting relationship between two faults, S1 then S2. (b) Successive stria, S1 then S2, on a fault plane.

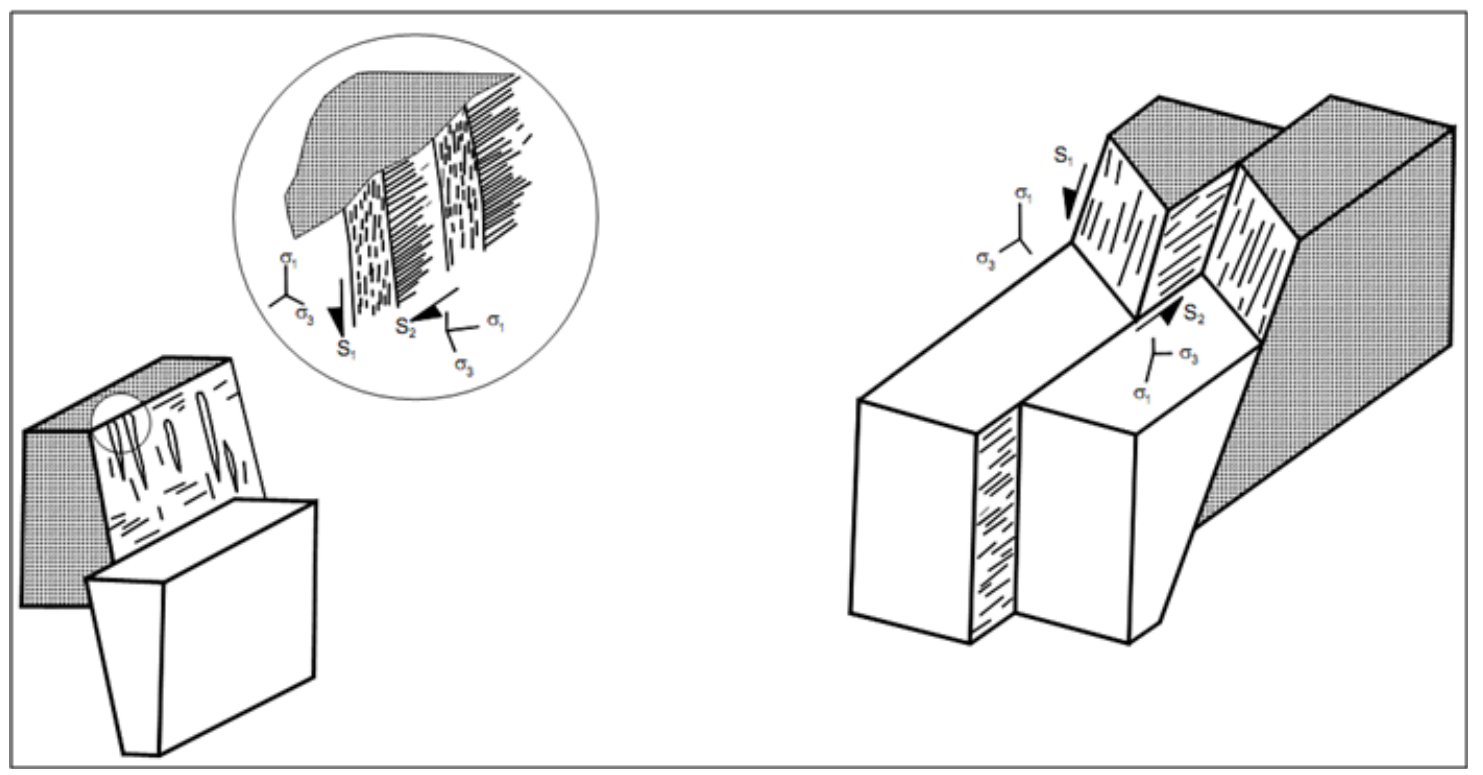

Fig.4. Faults plans, slikensides position and type of movement them. (a) Newest data, (b) Middle data, (c) Oldest data.

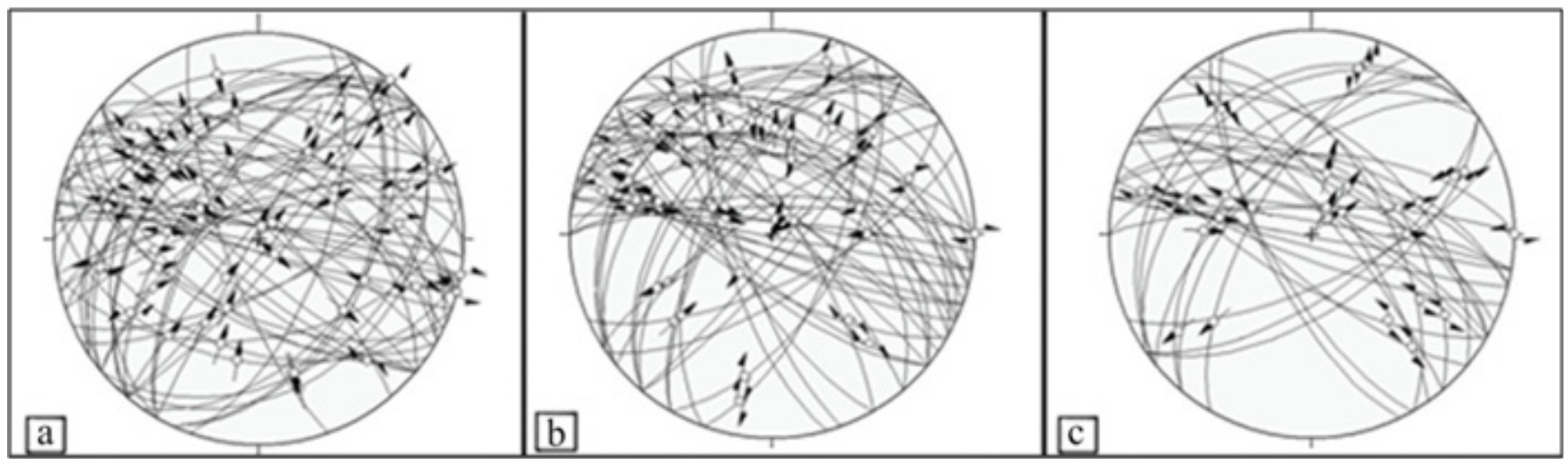




\subsection{Stress tensor determinations}

A systematic use of the direct inversion method, (Angelier, 1990) was made for analysis and computation of the stress axes. Briefly, the inversion is based on the minimization of the angle $(\alpha)$ between the real stria $\left(S_{k}\right)$ and the calculated relative shear stress $\left(\tau_{\mathrm{k}}\right)$ (Angelier, 1989). A crucial parameter in fault slip data inversion with multiple events is the minimum misfit level required for defining acceptable data. We use a scale from $100 \%$ (total misfit) to $100 \%$ (perfect fit). The lowest bound involves maximum shear stress acting in the direction opposite to slip. At the highest bound, the shear stress is also at the maximum value but acts in the same direction and sense as the slip. A zero value indicates a shear stress perpendicular to the slip, as the limit between consistent and inconsistent senses of motion. As pointed out elsewhere (Angelier, 2002), stability of the stress tensors obtained throughout the refining process provides evidence of stability of the solutions. Particular attention was paid to this evaluation of quality. Data sets with high levels of in homogeneity (heterogeneous sets) correspond to unstable solutions, and hence deserve rejection, or further analysis and separation into more separated components (e.g., polyphase sets).

After calculating the angle $(\alpha)$ and tensors that angle to reach the lowest, for each measure, there will be an angle $(\alpha)$ that are distributions. In Carey \& Brunier (Carey and Brunier, 1974) method, angle $(\alpha)$ to 30 degrees is acceptable and more that to be excluded from calculation. Fig. 5 shows discrepancies angle data distribution, after exclude more than 30 degree angles, in the different generations. Other than the stress tensor inversion mentioned above, a simple geometrical approach was also adopted. This approach involves the Right Dihedra, method (Angelier and Mechler, 1977). In this method, two nodal planes are considered (just as for focal mechanisms of earthquakes), with one being the actual fault plane. A simple geometrical restriction constrains the solid angles that maycontain the extreme principal stress axes. Considering these geometrical restrictions for all fault slips of a set, one obtains probability domains for the stress axes to occur (Gauthier and Angelier, 1985). Fig. 6 shows the result of this method.

Fig.5. Data discrepancies angle distribution, (a) Newest data, (b) Middle data, (c) Oldest data.

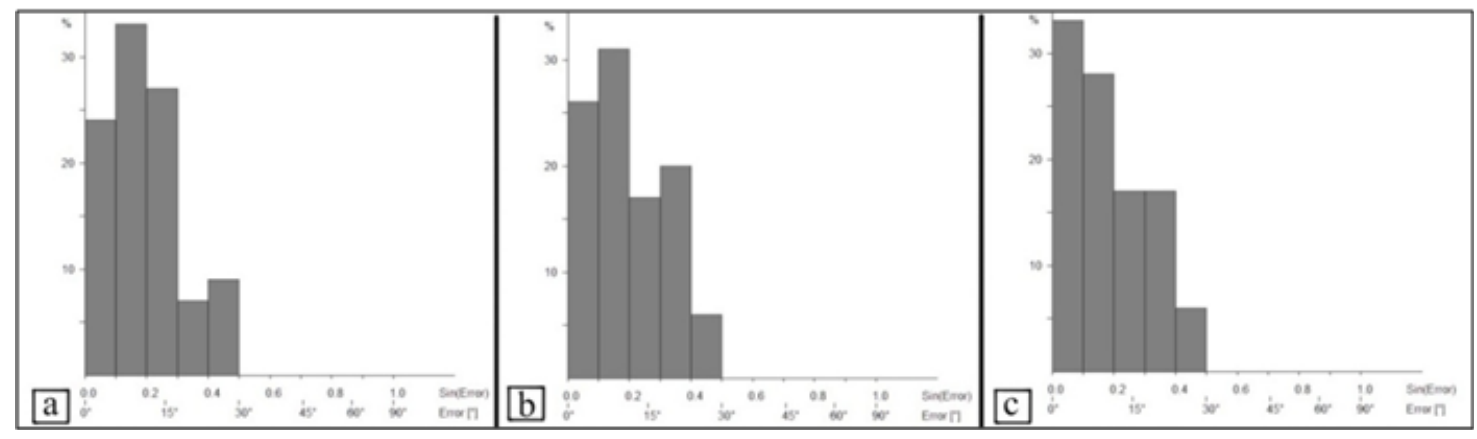

Fig.6. Results of Right Dihedra method, (a) Newest data, (b) Middle data, (c) Oldest data.

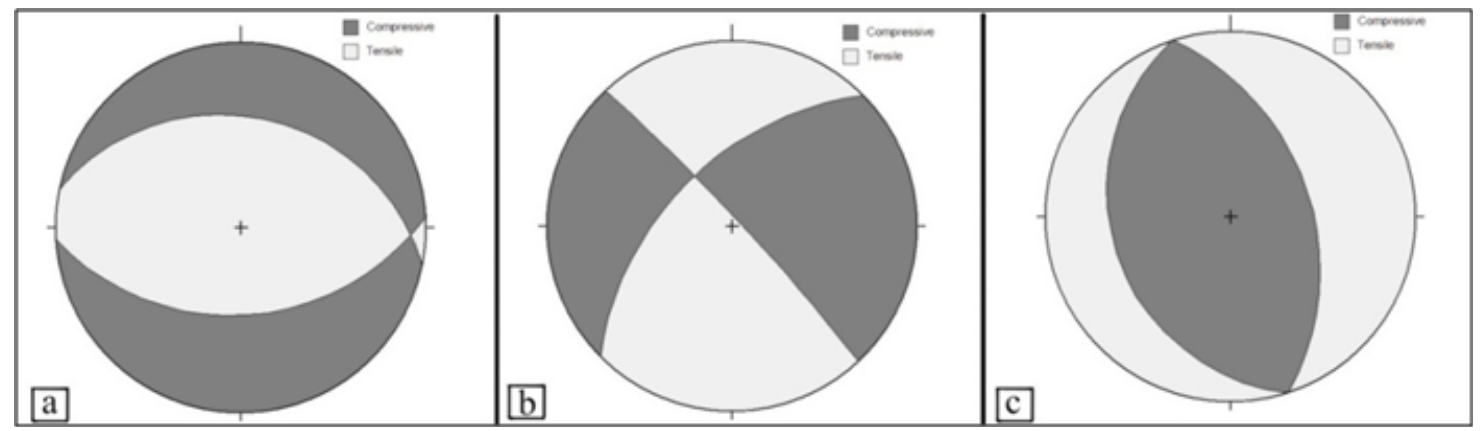

\section{Paleo stress reconstructions}

Systematic analysis of collected brittle tectonic data from studied area revealed a variety of stress regimes (strike-slip, compressional, and tensional in type) and stress directions in the studied area. The different stress regimes are characterised by different attitudes of the principal stress axes. In the tensional stress regime, the $\sigma_{2}$ and $\sigma_{3}$ stress axes are approximately horizontal and $\sigma_{1}$ stress axes are approximately vertical. This is the oldest known system in area, and the $\sigma_{1}$ axis is approximately SW-NE. In the strike-slip stress regime, the $\sigma_{1}$ and $\sigma_{3}$ stress axes are approximately horizontal and the $\sigma_{2}$ axis is approximately vertical. This is the middle known system in area, and the $\sigma_{1}$ axis is approximately E-W. In the compressional stress regime, the $\sigma_{1}$ and $\sigma_{2}$ axes are approximately 
horizontal and the $\sigma_{3}$ axis is approximately vertical. This system that is the newest known system in area, and the $\sigma_{1}$ axis is approximately N-S. The average position of stress main axies can be seen in Fig.7.

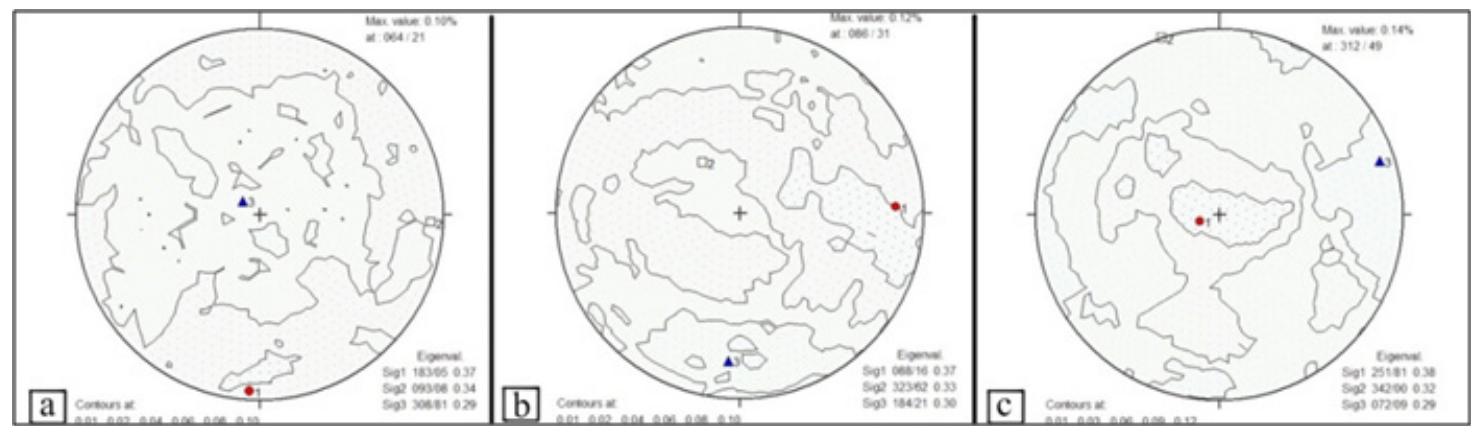

Fig.7. The average position of stress main axies, (a) Newest data, (b) Middle data, (c) Oldest data

\section{Discussion}

The brittle tectonic reconstructions presented in the previous sections indicated different fault systems with corresponding stress fields that developed during the located of ophiolites on the ground. This interaction resulted in the present-day structural complexity. Our analysis brought new approaches to the tectonic evolution of located of SOZ. In this section, we intend to discuss the paleostress results in relation to the SOZ structural evolution and regional tectonic framework. Due to large faults around each area are main factors to formation or defomation on area, we reviewed surrounding area main fault characteristics, that is called Miamey fault. This fault continues from East Shahroud to Afghanistan border. Nabavi (1976) said Miamey fault is continuing eastern of Attari fault or Semnan fault that likely continues to Harat fault in Afghanistan. Miamey fault is northern boundary of sabzevar-Shahroud rift. In based on Stampfli report (Stampfli, 2002), Miamey fault has been the right lateral movement to last phases of Alpian folding in Peliocen.

Fig.8. Rose Diagram of faults, (a) With strike and Length patameters, (b) With Length patameter.

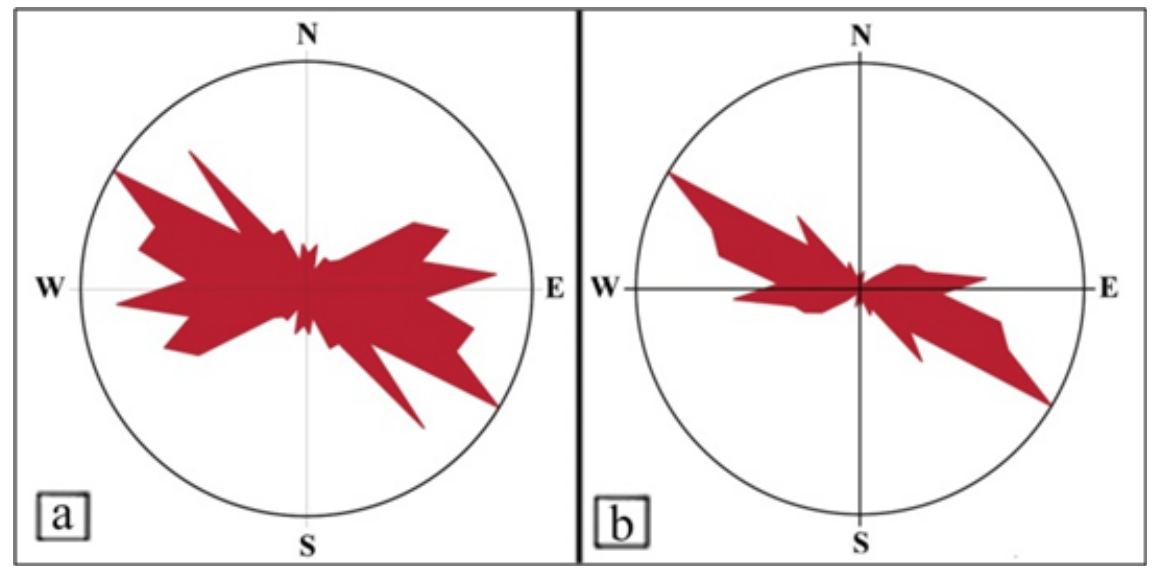

The reorientation of the stress field from SW-NE to the recent N-S direction, that is oblique to the NW-SE structural trend of the SOZ in the studied area (Fig.8), brought about right-lateral reactivations on many pre-existing belt-parallel brittle structures. This reactivation is clearly documented by brittle tectonic analyses of fault slip data in this study and it is reflected as a regional macro structure (Right-lateral motion of Miamey Fault) in the SOZ. Compression direction obtained in this study is consistent with studied about deformation of crust and recognition of plate movement in Iran and northern Oman, which is measured by GPS (Vernant et al., 2004). The active tectonics of Iran is dominated by the northward motion of Arabia with respect to Eurasia. At longitude 56E, $\sim 25$ $\mathrm{mm} / \mathrm{yr}$ of north-south shortening is accommodated across Iran. Shortening is accommodated by a combination of thrustand strike-slip faulting in seismically active parts of both southern and northern Iran.

Although more regional tectonic analyses are needed to reach firm conclusions, such changes could properly be the expression of the general ariation in convergence direction across plate boundaries. Thus, we think that this overall anticlockwise change in the direction of compression approximately resembles that suggested by McQuarrie et al. (McQuarrie et al., 2003) from plate tectonic reconstructions, and it is consistent with some similar features observed elsewhere in Iran such as South East Zagros Simply Folded 
Belt (Lacombe et al., 2006).

According to studies and on basis of Anderson's theory (Anderson, 1951), is obtained that, tensional stress regime is oldest stress generation in area and $\sigma_{1}$ stress axes are approximately vertical. Perhaps this can be justified such that, has occurred subsidence after translocation of the ophiolite onto continental crust and normal faults have developed in the area. Middle known system in area is strike-slip stress regime and the $\sigma_{2}$ axis is approximately vertical. This phase is transition from tension to compression that the change trend is done gradually.

Newest known system is compressional stress regime and the $\sigma_{3}$ axis is approximately vertical. In newest regime, $\sigma_{1}$ axis trend is approximately N183; this stress trend is result of Central Iran plate compression to Sabzevar Ophiolit Belt. Compression of Central Iran plate is affected by the Arabian plate pressure to it. Region general and newest stress systems direction (Approximately N121) is caused right-lateral reactivations on many pre-existing belt-parallel brittle structures. It is consistent with right-lateral movement of main structure of this region (Miamey fault). Finally, N-S compression direction that is clearly documented by brittle tectonic analyses of fault slip data in this study, Perfectly is consistent with studied about deformation of crust and recognition of plate movement in Iran and northern Oman, that is measured by GPS.

\section{References}

1 Anderson EM (1951) The dynamics of faulting and dyke formation with application to Britain. Oliver \& Boyd, Edinburgh.

2- Angelier J (1990) Inversion of field data in fault tectonics to obtain the regional stress. III. A new rapid direct inversion method by analytical means. Geophys. J. Int. 103, 363-376.

3. Angelier J (1989). From orientation to magnitudes in paleostress determinations using fault slip data, J. Struct.Geol. 11 (1/2), $37-50$.

4- Angelier J (2002) Inversion of earthquake focal mechanisms to obtainthe seismotectonic stress: a new method free of choice amongnodal planes. Geophys. J. Int. 150 (3), 588-609.

5• Angelier J and Mechler P (1977) Sur une method graphique derecherche des contraintes principales egalement utilisable en tectoniqueet en seismologie: la methode des diedresdroits. Bull. Soc. Geol. Fr. 7, XIX (6),1309-1318.

6• Bahroudi, A., Omrani, j., (1999). Geological Map of Bashtin. Geological Survey of Iran, 1:100000.

7• Carey E and Brunier B (1974) Analyse theoriqueetnumerique dun model emecanique elementaire applique letude dune populationde failles. C. R. Acad. Sci. Paris D 279, 891-894.

8- Gauthier B and Angelier J (1985) Fault tectonics and deformation: a method of quantification using field data. Earth Planet. Sci. Lett. 74,137-148.

9• Lacombe O, Mouthereau F, Kargar Sh. and Meyer B (2006) Late Cenozoic and modern stress fields in the western Fars (Iran): implications for the tectonic and kinematic evolution of central Zagros. Tectonics 25, TC1003. doi:10.1029/2005TC001831.

10• McQuarrie N, M. Stock J, Verdel C and Wernicke BP (2003) Cenozoic evolution of Neotethys and implications for the causes of plate motions. Geophys. Res. Lett. 30 (20).

11 Mirzeinali SH (2012) Stress orientation in Sabzevar Ophiolite Zone. Ph.D. Thesis, Department of Geology, Science and Research Branch Islamic Azad University, Tehran, Iran (In Farsi).

12- Navabpour P, Angelier J and Barrier E (2007) Cenozoic post- collisional brittle tectonic history and stress reorientation in the High Zagros Belt (Iran, Fars Province).Tectonophysics. 432, 101-131.

13. Stampfli G and Borel GD (2002) A plate tectonic model for the Palaeozoic and Mesozoic constrained by dynamic plate boundariesand restored synthetic oceanic isochrones. Earth Planet. Sci. Lett.196,17-33.

14- Stocklin J (1968) Structural history and tectonics of Iran, a review. Am. Assoc Petrol. Geol. Bull. 52,1229-1258.

15- Nabavi M (1976) An introduction to the Iranian geology. Geological Survey of Iran, (in Farsi).

16- Vahidinia M and Ariae A (1999) Determine Age of the Sabzevar ophiolite melange based on paleontology and its comparison with radiometry data. Third Conf. of the Geological Soc. of Iran.

17• Vernant Ph, Nilfroushan F, Hatzfeld D, Abbassi MR, Vigny C, Masson F, Nanakali H, Ashtiani A, Bayer R, Tavakoli F and Chery J (2004) Contemporary crustal deformation and plate kinematics in Middle East constrained by GPS measurements in Iran and northern Oman. Geophys. J. Int. 81, 398. 